\title{
Precolostral evaluation of Bovine Enterovirus Type 1 (BEV1) infection in a dairy herd
}

\author{
Fatih M. Birdane ${ }^{1}$, and Sibel Gür ${ }^{2 *}$ \\ ${ }^{1}$ Department of Internal Medicine, Faculty of Veterinary Medicine, Afyon Kocatepe University, \\ Afyonkarahisar, Turkey \\ ${ }^{2}$ Department of Virology, Faculty of Veterinary Medicine, Afyon Kocatepe University, Afyonkarahisar, Turkey
}

\section{BIRDANE, F. M., S. GÜR: Precolostral evaluation of Bovine Enterovirus Type 1 (BEV1) infection in a dairy herd. Vet. arhiv 89, 1-10, 2019. \\ ABSTRACT}

Bovine Enterovirus Type 1 (BEV1) is a viral infection affecting the respiratory, alimentary and reproduction systems, and is accepted as an environmental pollutant due to its resistant features over a long period of time under field conditions. Since calves are born agamaglobulinemic due to syndesmochorial placenta features that block immunoglobulin transfer to the fetus from the dam, the presence of precolostral antibodies directly reflects the defeat of an in-utero infection in the last five months of gestation. In this study, BEV1 was investigated serologically in dams and their precolostral calves. The Virus Neutralisation Test (VNT) was preferred due to its high sensitivity and specificity. The samples were collected simultaneously, shortly after parturition on a largescale dairy farm. The results of the test showed that $98.7 \%(153 / 155)$ of the dams were seropositive for BEV1. The average antibody $(\mathrm{Ab})$ titer was the highest at $1 / 20$ dilution. Out of 155 precolostral calves, specific Abs were determined in $8(5.1 \%)$. The $\mathrm{Ab}$ titer distributions in the calves varied between $1 / 5$ and $1 / 40$, and the peak dilution point was $1 / 10$ in calves while it was $1 / 80$ in their dams. Current veterinary practice is long outdated and needs to be replaced by preventive programs to combat diseases, which are crucial, especially for dairy herds. Precolostral $\mathrm{Ab}$ control of newborn calves is preferred as a useful, feasible and reliable tool for detecting recent infections to discover the risks.

Key words: Bovine Enterovirus Type 1; ECBO virus; precolostral; serocontrol

\section{Introduction}

Picornaviridae form an extensive family of large RNA viruses whose natural hosts comprise many species, including humans. Bovine Enterovirus (BEV) subtypes have been classified into two serotypes (KNOWLES and BARNETT, 1985; KING et al., 2000; ZELL et al., 2006). Recently, BEVs were taxonomically grouped into A-J and A-C

\footnotetext{
${ }^{*}$ Corresponding author:

Sibel Gür, PhD, DVM, Afyon Kocatepe University, Faculty of Veterinary Medicine, Department of Virology, ANS Campus, 03200 Afyonkarahisar, Turkey, Phone: +90 05364372 882; Fax: +90 02722281 349, E-mail: sibelgur@aku.edu.tr
} 
(KNOWLES et al., 2012). Although the host spectrum of type 2 is limited only to cattle, type 1 has quite a wide host spectrum, including cattle, water buffalo (MEHROTRA, 1973), sheep, goats (JAIN et al., 1985), African buffalo, impala (HAMBLIN et al., 1985), humans (McFERRAN, 1962; YAMADA, 1965), etc.

Like all the other Picornaviruses, BEV is highly resistant to environmental conditions, such as pH (2-10) (TAYLOR et al., 1974), high temperature and salinity (LEY et al., 2002), and to many chemical disinfectants (MAHNEL, 1974). It is counted as an environmental pollutant. The transmission route is fecal-oral. The virus is shed in extremely high amounts in feces from both clinically and subclinically infected individuals (TAYLOR et al., 1974). After transmission, the virus reaches the intestines without any effect due to its acid stability, passes to the lymph nodes and induces an antibody $(\mathrm{Ab})$ response, generally without causing any plain signs. The agent may be isolated from both healthy and sick cattle. Prominent disorders are seen in the alimentary tract (McFERRAN, 1962), and the respiratory (MOLL and ULRICH, 1963; McCLURKIN, 1976) and reproductive systems (DUNNE et al., 1974).

Viremia during acute infections has the potential of in-utero transmission at any time during gestation, resulting from the overt or subclinical maternal infection of the dam. The risk is higher especially in intensive dairy breeding farms. The syndesmochorial placenta features in ruminants form a syncytium between the endometrium and the fetal trophectoderm. These structures create a barrier between maternal and fetal blood circulation. Consequently, no immunoglobulins may pass to the fetus from the dam in-utero (ARTHUR, 1996). The outcomes of infections are related to age (the immune competent status of the fetus) alongside the features of the microorganisms. Fetal consequences include abortion, intrauterine growth retardation, premature birth, stillbirth, congenital anomalies, and symptomatic or asymptomatic infection. Embryonic infections generally result in death, but immune-competent fetuses have a chance of survival. Few viral, bacterial and parasitic infections have been investigated precolostrally so far (BOSCH et al., 2000; STAUBLI et al., 2006; SCHEFERS et al., 2008; OZEL and GUR, 2015).

In this study, BEV1 status was investigated serologically in precolostral calves and their dams in a closed system intensive dairy farm.

\section{Materials and methods}

Sampled animals. In this study, blood sera samples were obtained from a closed system intensive dairy cattle enterprise in Afyonkarahisar province, Central Anatolia. There were over 1500 cattle in different age groups, and the number of fertile cows was approximately 1100 , at the time of sampling. Blood samples were collected just after birth from 155 dams and their precolostral calves simultaneously, within a three-month period. 
All the sampled animals were clinically normal during sampling. According to regular health reports on the herd, diarrhea and pneumonia in calves and various reproductive problems and mastitis problem in cows had increased especially in the past year. Blood samples were taken by vena-puncture from the jugular vein into vacutainer tubes with silicon and transferred to the laboratory in a cold chain. The samples were centrifuged at $3000 \mathrm{~g}$ for $10 \mathrm{~min}$. Serum fractions were separated into the stock tubes, and stored at -20 ${ }^{\circ} \mathrm{C}$ until the tests.

Cell culture. Madine Darby bovine kidney (MDBK) cell culture (ATCC, CCL22) was used for virus propagation, titration and microneutralisation tests. Dulbecco's Minimal Essential Medium (DMEM) containing 2-10\% fetal calf serum (FCS) was used as the cell culture medium.

Virus. Bovine enterovirus type 1, enteric cytopathogenic bovine orphan (ECBO) virus, strain LC-R4 (ATCC VR-248) (10-3.5 TCID50/0.1 mL) was used as the test virus, which was isolated in Michigan in 1957 (KUNIN and MINUSE, 1958), and classified in group 1 cluster A. The tissue culture infective dose of 50\% (TCID50) of the virus suspension was calculated by the Spearman and Kaerber method (OSTERKORN, 1982).

Virus Neutralisation Test (VNT). For detection of the presence of BEV-1 specific ab, a standard micro virus neutralization test was carried out (FREY and LIESS, 1971). For this purpose, centrifuged and separated serum samples were inactivated at $56{ }^{\circ} \mathrm{C}$ for 30 min. and stored at $-20^{\circ} \mathrm{C}$ until testing. All serum samples were thawed and diluted to $1 / 5$ with cell culture medium. After that, $50 \mu \mathrm{L}$ of the dilution was added to two wells of the tissue culture plates with the same volume of virus suspension, containing approximately 100 TCID per $50 \mu \mathrm{L}$. After $1 \mathrm{~h}$ of incubation, $50 \mu \mathrm{L}$ cell suspensions $(300.000$ cells/ $\mathrm{mL}$ ) were added and incubated at $37{ }^{\circ} \mathrm{C}$ with $5 \% \mathrm{CO}_{2}$ for two days. Test results were determined based on the micromorphology of the cells using an inverted microscope over the subsequent two days.

All BEV-1 Ab positive serum samples were subsequently diluted to 1/5, 1/10, 1/20, $1 / 40,1 / 80,1 / 160$ and re-tested as outlined above, to determine the Abs titer values.

\section{Results}

$V N T$. According to the test results, a 1/5 dilution and above was accepted as seropositive. BEV1 specific Ab was in 153 of 155 dams (98.7\%). As can be seen in Fig. 1, the regular bell curve distribution's peak point was at $1 / 20$. A slight increase was observed from the $1 / 80$ dilution point. 
F. M. Birdane and S. Gür: Precolostral evaluation of Bovine Enterovirus Type 1 (BEV1) infection in a dairy herd

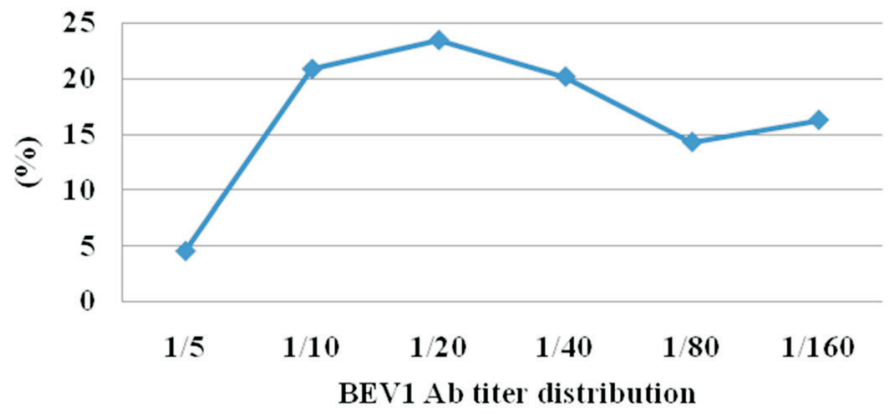

Fig. 1. BEV1 Ab titer distribution of dams

Out of the precolostral calves, $8(5.1 \%)$ were $\mathrm{Ab}$ positive at between $1 / 5$ and $1 / 40$ titer values. The Ab titer values of the positive calves and their dams are shown in Fig. 2 .

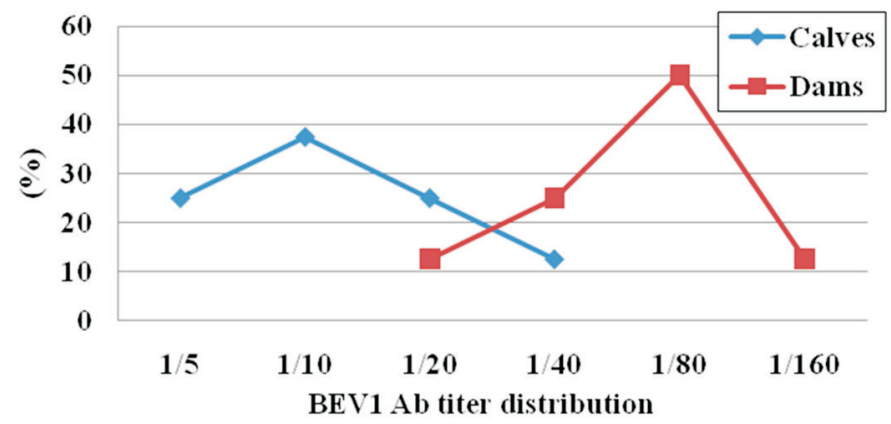

Fig. 2. BEV1 Ab titer distribution of precolostral calves and their dams

\section{Discussion}

Serological controls provide valuable data in determining the status of herds regarding both acute and latent/persistent infections. Testing for $\mathrm{Ab}$ presence and titer values at a single time point does not give enough data to determine acute infection without a second control in a two-week interval. Deviant Ab titer values are frequently seen despite routine vaccinations.

Outcomes of transplacental infection are a well-known phenomenon, especially for Bovine Viral Diarrhea Virus (BVDV) infection in cattle. Pathogenetic studies have shown that the earliest dates of neutralizing $\mathrm{Ab}$ formation as a result of maternal BVDV infection were determined as the $79^{\text {th }}$ (SCOTT et al., 1973) and $93^{\text {rd }}$ days of gestation (KENDRICK, 1971). Considering the immune competence development period, precolostral $\mathrm{Ab}$ 
examinations directly reveal circulating infections in the herd in approximately the previous five months.

In this study, BEV1 seropositivity was $98.7 \%$ in the dams while it was $5.1 \%$ in their precolostral calves. Prenatally synthesized antibodies reflected intrauterine exposure and successfully overcome BEV1 infection. Nearly all the dams were infected with the virus $(\mathrm{n}=153 / 155)$. However, mean Ab titer rates differed greatly between the cattle overall (average 1/20) and the dams of the seropositive calves (average 1/80) (Fig 1-2). There are no data on the duration of the half-life of BEV1 specific Abs, but dams of precolostral calves had evidently had more recent infections than other cattle in view of the significantly higher $a b$ titer rates than expected.

According to the health records of the dairy herd studied, there was mild level diarrhea and pneumonia in almost one-third of the newborns and older calves. Additionally, a prolonged service period and infertility were seen in some cows. Reproductive disorders in cattle and alimentary-respiratory tract problems in calves could be related to BEV, but the clinical findings were far from providing a specific diagnosis in the absence of lab controls. There was no record on abortion and stillbirth in the studied herd. Previously, a BVDV eradication study was performed on all the animals in the herd. According to the previous controls, the BVDV Ab rate was $98.2 \%$ in six month old and older individuals. Persistent infection was seen in five cattle, which was later eradicated after second tests. BHV1 seropositivity was $95.6 \%$ in adult cattle despite the absence of vaccination. Additionally, one precolostral calf $(0.6 \%)$ was BHV1 seropositive (OZEL and GUR, 2015).

Virus isolation and sera-survey studies under field conditions reveal the presence of the infection all over the world (HAMBLIN et al., 1985; SHAUKAT et al., 2012; ZHANG et al., 2014; SOBHY et al., 2015; HE et al., 2017). Serologic investigations have also shown the high prevalence in Turkey. In the first study, 53\% seropositivity was found in 480 cattle from 10 different enterprises (ALKAN et al., 1997). The lowest data reported in buffaloes were 3.99\% (14/355) (GUR et al., 2006). In a large-scale survey, BEV1 was serologically detected in humans $(30.3 \%)$, cattle $(64.8 \%)$, horses $(12.8 \%)$, dogs (3.2\%), sheep (32.8\%) and goats (27.6\%) (GUR et al., 2008) and buffaloes (13.1\%) (GUR et al., 2004). In goats, a prevalence of 53.3\% (736/1.380) was reported in the provinces of Central Anatolia. The rates varied between 17.6\% and 80\% (ACAR and GUR, 2009). According to a recent study conducted on humans, seropositivity rates did not show significant differences between people living in the city center and rural areas (Unpublished data).

The vast majority of BEV1 infections are subclinical, but occasionally severe or fatal cases have been described in different parts of the world. In the past decade, fatal enteric disease in a 2 year old heifer (BLAS-MACHADO et al., 2007), fatal respiratory disorder 
in an Alpaca in the USA (McCLENAHAN et al., 2013), and severe respiratory and enteric disease in China (ZHU et al., 2014) have been reported. Diarrheal disease with poor prognosis was also described recently in a yak in Tibet (HE et al., 2017). However, the current literature contains relatively limited data on the pathogenesis and virulence of the virus in cattle and other species determined to be susceptible.

\section{Conclusion}

No clinical case has been reported in Turkey so far, but the current data are limited to a serosurvey. Due to the absence of virus isolation or antigen detection, circulating biotypes are unknown. The contribution of BEV1 to the disorders mentioned in the herd was not totally clear considering the presence of a high rate of natural BVDV and BHV1 infections. However, its role in the general prognosis must not be disregarded in the light of the obtained data. There is no prophylactic material such as a specific vaccine against BEV1. Preventive measures for noticeable infections and ensuring good herd management conditions are the only solution to prevent economic loses.

A holistic approach to sustainable herd management is the backbone of intensive dairy herds, especially in countries that have a high presence of infections of major veterinary importance. BEV1 is not one of these but may contribute to a poor prognosis. The infection was determined precolostrally for the first time in this study. Precolostral sampling can be difficult under field conditions but sera-control of neonates before colostrum intake could be recommended due to its high potential to provide quite valuable data regarding the recent circulation of various infections.

\section{Acknowledgements}

The authors are thankful to the Farm Veterinarians for their support in sharing health records and help during the sampling process.

\section{References}

ACAR, A., S. GUR (2009): Seroprevalence of Bovine Enterovirus Type 1 (BEV1) in goats in Turkey. J. Anim. Vet. Adv. 8, 1075-1078.

ALKAN, F., A. OZKUL, M. T. KARAOGLU, S. BILGE, Y. AKCA, I. BURGU, K. YESILBAG, T. C. OGUZOGLU (1997): Seroepidemiological studies on respiratory infections of cattle caused by viruses. Ankara. Univ. Vet. Fak. Derg. 44, 73-80 (in Turkish).

ARTHUR, G. H. (1996): The development of the conceptus. In: Pregnancy and Parturition in Veterinary Reproduction and Obstetrics. $7^{\text {th }}$ ed., (Arthur, G. H., D. E. Nokes, H. Pearson, T. J. Parkinson, Eds.), WB Saunders, Philadelphia, USA, pp. 51-109. 
F. M. Birdane and S. Gür: Precolostral evaluation of Bovine Enterovirus Type 1 (BEV1) infection in a dairy herd

BLAS-MACHADO, U., J. T. SALIKI, M. J. BOILEAU, S. D. GOENS, S. L. CASELTINE, J. C. DUFFY, R. D. WELSH (2007): Fatal ulcerative and hemorrhagic typhlocolitis in a pregnant heifer associated with natural Bovine Enterovirus type-1 infection. Vet. Pathol. 4, 110-115.

DOI: $10.1354 / v p .44-1-110$

BLAS-MACHADO, U., J. T. SALIKI, S. SANCHEZ, C. C. BROWN, J. ZHANG, D. KEYS, A. WOOLUMS, S. B. HARVEY (2011): Pathogenesis of a Bovine Enterovirus-1 isolate in experimentally infected calves. Vet. Pathol. 48, 1075-1084.

DOI: $10.1177 / 0300985810395728$

BOSCH, J. C., J. A. VAN LIESHOUT, J. J. DE WIT, E. A. GRAAT, M. J. SOMERS (2000): The serological BHV1 status of dams determines the precolostral status of their calves.Vet. Q. 22, 99-102.

DOI: $10.1080 / 01652176.2000 .9695033$

DUNNE, H. W., C. M. HUANG, W. J. LIN (1974): Bovine enteroviruses in the calf: an attempt at serologic, biologic and pathologic classification. J.A.V.M.A. 164, 290-294.

FREY, H. R., B. LIESS (1971): Multiplication kinetics and usability of a strong cytopathogenic VD-MD virus strain for diagnostic studies using the microtiter method. Zbl. Vet. Med. 18, 61-71 (in German).

DOI: 10.1111/j.1439-0450.1971.tb00343.x

GUR, S., M. T. TAN, I. OZGUNLUK (2004): Serological investigation of bovine enterovirus (BEV) types 1 and 2 in cattle in Aydın province. Pendik Vet. Mikrobiol. Derg. 35, 3-6 (in Turkish).

GUR, S., Y. AKCA, I. BURGU (2006): Serological investigation of bovine enterovirus type-1 in buffaloes in Turkey. Ankara Univ. Vet. Fak. Derg. 53,191-194 (in Turkish).

GUR, S., O. YAPKIÇ , A. YILMAZ (2008): A serologic investigation of Bovine Enterovirus type 1 in different mammalian species in Turkey. Zoonoses Publ. Health. 55, 106-111. DOI: $10.1111 /$ j.1863-2378.2007.01095.x

HAMBLIN, C., N. J. KNOWLES, R. S. HEDGER (1985): The isolation and identification of bovid enteroviruses from free-living wild animals in Bostwana. Vet. Rec. 116, 238-239.

DOI: $10.1136 /$ vr.116.9.238

HE, H., C. TANG, X. CHEN, H. YUE, Y. REN, Y. LIU, B. ZHANG (2017): Isolation and characterisation of a new enterovirus $\mathrm{F}$ in yak feces in the Qinghai-Tibetan Plateau. Arch. Virol. 162, 523-527.

DOI: $10.1007 / \mathrm{s} 00705-016-3119-\mathrm{x}$

JAIN, N. C., S. K. BATRA (1985): Isolation and characterisation of ovine enteroviruses. Ind. J. Virol. 1, 17-25.

KENDRICK, J. W. (1971): Bovine Viral Diarrhea - mucosal disease virus infection in pregnant cows. Am. J. Vet. Res. 35, 589-591.

Vet. arhiv 89 (1), 1-10, 2019 
F. M. Birdane and S. Gür: Precolostral evaluation of Bovine Enterovirus Type 1 (BEV1) infection in a dairy herd

KING, A. N. Q., F. BROWN, T. CHRISTIAN, T. HOVI, T. HYYPIA, N. J. KNOWLES, S. M. LEMON, P. D. MINOR, A. C. PALMENBERG, T. SKERN, G. STANWAY (2000): Picornaviridae. In: Virus Taxonomy. Seventh report of the International Committee for the Taxonomy of Viruses. (Van Regenmortel, M. H. V., C. M. Fauquet, D. H. L. Bishop, C. H. Calister, E. B. Carsten, M. K. Estes, S. M. Lemon, J. Maniloff, M. A. Mayo, D. J. McGeoch, C. R. Pringle, R. B. Wickner, Eds.), Academic Press, San Diego, California, pp. 657-678.

KNOWLES, N. J., T. HYYPIA, A. M. Q. KING, M. LINDBERG, M. A. PALLANSCH, A. C. PALMENBERG, P. SIMMONDS, T. SKERN, G. STANWAY, T. YAMASHITA, R. ZELL (2012): Picornaviridae. In: Virus Taxonomy: Classification and Nomenculature of Viruses: Ninth report of the International Committee on Taxonomy of Viruses. Elsevier, San Diego, pp. 855-880.

KNOWLES, N. J., I. T. R. BARNETT (1985): A serological classification of bovine enteroviruses. Arch. Virol. 83, 141-155.

DOI: $10.1007 / \mathrm{BF} 01309912$

KUNIN, C. M., E. MINUSE (1958): The isolation in tissue culture, chick embryo and suckling mice of filtrable agents from healthy dairy cattle. J. Immunol. 80, 1-11.

LEY, V., J. HIGGING, R. FAYER (2002): Bovine enteroviruses as indicators of fecal contamination. Appl. Env. Microbiol. 68, 3455-3461.

DOI: 10.1128/AEM.68.7.3455-3461.2002

MAHNEL, H. (1974): Virucidal effect of disinfectants in the suspension test. Berl. Munch. Tierarztl. Wochenschr. 87, 385-388 (in German).

McCLENAHAN, S. D., G. SCHERBA, L. BORST, R. L. FREDRICKSON, P. R. KRAUSE, C. UHLENHAUT (2013): Discovery of a Bovine Enterovirus in Alpaca. Plos One, 8:e68777.

DOI: 10.1371/journal.pone.0068777

McCLURKIN, A. W. (1976): Symposium: Calfhood diseases and immunisation programs. Probable role of viruses in calfhood diseases. J. Dairy Sci. 60, 278-282.

DOI: $10.3168 /$ jds.S0022-0302(77)83865-4

McFERRAN, J. B. (1962): Bovine enteroviruses. N. Y. Acad. Sci. 101, 436-443.

DOI: $10.1111 / j .1749-6632.1962 . t b 18883 . x$

MEHROTRA, M. L. (1973): Isolation and characterisation of cytopathogenic viral agents resembling enteroviruses of buffalo. Ind. J. Anim. Sci. 43, 624-628.

MOLL, T., M. ULRICH (1963): Biologic characteristics of certain bovine enteric viruses. Am. J. Vet. Res. 24, 545-550.

OSTERKORN, K. (1982): Biometric methods. In: Virological Working Methods. Band IV. Gustav Fischer Verlag, Stuttgart (in German).

OZEL, M., S. GUR (2015): Serological investigation for Bovine Viral Diarrhea and Bovine Herpesvirus Type-1 Viruses in precolostral calves and their dams. Harran Univ. Vet. Fak. Derg. 4, 57-63. 
F. M. Birdane and S. Gür: Precolostral evaluation of Bovine Enterovirus Type 1 (BEV1) infection in a dairy herd

SCOTT, F. W., R. F. KAHRS, A. DELAHUNTA, T. T. BROWN, K. MCENTEE, J. H. GILLESPIE (1973): Virus induced congenital anomalies of the bovine fetus. I. Crebellar degeneration (hypoplasia), ocular lesions and fetal mummification following experimental infection with bovine Viral Diarrhea-mucosal disease virus. Cornell Vet. 63, 536-560.

SHAUKAT, S., M. ANGEZ, M. M. ALAM, S. AHARIF, A. KHURSID, F. MALIK, M. S. RANA, T. MAHMOOD, S. S. Z. ZAIDI (2012): Molecular identification and characterisation of a new type of bovine enterovirus. Appl. Environ. Microbiol. 78, 4497-4500.

DOI: $10.1128 / A E M .00109-12$

SCHEFERS, J., C. MUNOZ-ZANKI, J. E. COLLINS, S. M. GOYAL, T. R. AMES (2008): Serological evaluation of precolostral serum samples to detect Bovine viral diarrhea virus infections in large commertial dairy herds. J. Vet. Diagn. Invest. 20, 625-628.

DOI: $10.1177 / 104063870802000515$

SOBHY, N. M., S. K. MOR, M. E. M. MOHAMMED, I. M. BASTAWECY, H. M. FAKHRY, C. R. B. YOUSSEF, N. Z. ABOUZEID, S. M. GOYAL (2015): Isolation and molecular characterisation of bovine enteroviruses in Egypt. Vet. J. 206, 317-321.

DOI: $10.1016 / j . t v j 1.2015 .10 .011$

STAUBli, D., H. SAGER, C. HAERDI, M. HAESSIG, B. GOTTSTEIN (2006): Precolostral serology in calves born from Neospora-seropositive mothers. Parasitol. Res. 99, 394-404.

DOI: $10.1007 / \mathrm{s} 00436-006-0170-7$

TAYLOR, M. W., R. SU, B. CORDELL-STEWART, S. MORGAN, M. CRISP, M. E. HODES (1974): Bovine Enterovirus-1: characterisation, replication and cytopathogenic effect. J. Gen. Virol. 23, 173-178.

DOI: $10.1099 / 0022-1317-23-2-173$

YAMADA, S. (1965): Studies on bovine enteroviruses. IV. Neutralizing antibodies in the Kyushu district. Jpn. J. Vet. Sci. 27, 317-323.

DOI: $10.1292 /$ jvms1939.27.317

ZELL, R., A. KRUMBHOLZ, M. DAUBER M, E. HOEY, P. WUTZLER (2006): Molecular-based reclassification of the bovine enteroviruses. J. Gen. Virol. 87, 375-385.

DOI: $10.1099 /$ vir.0.81298-0

ZHANG, H., H. LIU, J. BAO, Y. GUO, T. PENG, P. ZHOU, W. ZHANG, B. MA, J. WANG, M. GAO (2014): Characterization of an Enterovirus species E isolated from naturally infected bovine in China. Virus Res. 191, 101-107.

DOI: 10.1016/j.virusres.2014.07.032

ZHU, L., Z. XING, X. GAI, S. LI, Z. SAN, W. WANG (2014): Identification of a novel Enterovirus E isolates HY12 from cattle with severe respiratory and enteric diseases. Plos One. 9(5), e97730.

DOI: 10.1371/journal.pone.0097730

Vet. arhiv 89 (1), 1-10, 2019 
F. M. Birdane and S. Gür: Precolostral evaluation of Bovine Enterovirus Type 1 (BEV1) infection in a dairy herd

Received: 21 November 2017

Accepted: 5 November 2018

\section{BIRDANE, F. M., S. GÜR: Procjena infekcije goveđim enterovirusom tipa 1 (BEV1) u stadu mliječnih goveda prije uzimanja kolostruma. Vet. arhiv 89, 1-10, 2019. SAŽETAK}

Infekcija goveđim enterovirusom tipa 1 (BEV1) zahvaća dišni, probavni i reproduktivni sustav, a virus se smatra onečišćivačem okoliša zbog visoke otpornosti na vanjske uvjete. S obzirom na to da se telad rađa $\mathrm{s}$ agamaglobulinemijom zbog sindesmohorijalne placente koja sprečava prijenos imunoglobulina s majke na plod, prisutnost protutijela prije uzimanja kolostruma izravno upućuje na dijaplacentarnu infekciju u posljednjih pet mjeseci bređosti. U ovom je istraživanju BEV1 ispitivan serološkim metodama u krava i njihove teladi. Uzorci su analizirani virus-neutralizacijskim testom (VNT) zbog njegove visoke osjetljivosti i specifičnosti. Uzorci su prikupljeni istodobno, odmah nakon teljenja na farmi mliječnih krava. Test je pokazao da je 98,7 \% krava (153 od 155) seropozitivno na BEV1. Prosječan titar protutijela bio je najviši pri razrjeđenju $1: 20$. Od 155 telića prije uzimanja kolostruma specifična su protutijela pronađena u njih $8(5,1 \%)$. Titar protutijela među telićima varirao je između $1: 5$ i $1: 40$, a najviši je titar utvrđen pri razrjeđenju $1: 10$ u telića, odnosno $1: 80$ u krava. Sadašnja je veterinarska praksa odavno zastarjela i zamijenjena je prevencijom bolesti što je u stadima mliječnih goveda ključno. Praćenje protutijela na BEV1 u novorođene teladi prije uzimanja kolostruma jest korisna, izvediva i pouzdana metoda otkrivanja zaraze i razumijevanja rizika od zaraze.

Ključne riječi: goveđi enterovirus tipa 1; ECBO virus; kolostrum; serokontrola 